\title{
Isotope Compositions of Three Synthetic Andesite Reference Glass Materials (ARM-1, ARM-2, ARM-3) for In Situ Microanalysis
}

\author{
Shitou Wu*, Yueheng Yang, ChaO HuAng, HaO \\ WANG, LIEWEN XIE AND JINHUI YANG \\ ${ }^{1}$ State Key Laboratory of Lithospheric Evolution, Institute of \\ Geology and Geophysics, Chinese Academy of Sciences, \\ Beijing 100029, P.R.China. shitou.wu@ mail.iggcas.ac.cn
}

Three newly synthetic reference glasses have been recently prepared to provide reference materials for microanalytical work ${ }^{1}$. These glasses have andesitic major compositions, and are doped with fifty-four trace elements in nearly identical abundance $\left(500,50,5 \mu \mathrm{g} \mathrm{g}^{-1}\right)$. They are named ARM-1, 2 and 3, respectively. To further establish their usage in field of isotope microanalysis, we undertook extensive analytical work on $\mathrm{Li}, \mathrm{B}, \mathrm{O}, \mathrm{Mg}, \mathrm{Fe}, \mathrm{Ca}, \mathrm{Sr}, \mathrm{Nd}$, $\mathrm{Hf}, \mathrm{Pb}$, and $\mathrm{U}$ isotopes using various in situ and bulk techniques, including LA-MC-ICP-MS, MC-ICP-MS, SIMS, Laser Fluorination, and TIMS. Homogeneity of $\mathrm{Li}, \mathrm{O}$, and $\mathrm{Pb}$ was further evaluated through multiple spot analyses on different glass splits. The results indicate that these reference glasses are homogeneous with respect to $\mathrm{Li}, \mathrm{O}$, and $\mathrm{Pb}$ isotopes. This study provides the preliminary isotope data for the ARM glasses. Most of them were measured using two independent techniques (MC-ICP-MS and TIMS) from two or three independent laboratories. These new isotope data might be useful in the geochemical community for in situ and bulk isotopic analysis. We are willing to distribute apprapriate but limited amounts of the ARM glasses to the scientific community on request (S. Wu, email: shitou.wu@mail. iggca $\underline{\text { s.ac.cn) }}$

References

1. S. Wu, G. Wörner, K. P. Jochum, B. Stoll, K. Simon and A. Kronz, Geostand. Geoanal. Res., 2019, 43, 567-584 